\title{
ANALISIS LAJU SEDIMENTASI, UNSUR HARA SEDIMEN DAN UJI KEMAMPUAN NITRIFIKASI BAKTERI Nitrosomonas SEBAGAI DATA DASAR UNTUK RESTORASI KUALITAS AIR PADA BUDI DAYA KERAMBA JARING APUNG
}

Endi Setiadi Kartamihardja*; dan Hambali Supriyadi")

\begin{abstract}
ABSTRAK
Degradasi kualitas perairan waduk sebagai akibat aktivit as budi daya ikan dalam keramba jaring apung telah terjadi di Waduk Saguling, Cirata dan Jatiluhur. Penelitian restorasi (perbaikan) kualitas perairan melalui pendekatan eko-tcknologi telah dilakukan di ketiga perairan yang telah mengalami degradasi tersebut. Tujuan penelitian ini adalah untuk mendapatkan informasi dasar mengenai: (a) laju sedimentasi dari kegiatan budi daya ikan di KJA: (b) kandungan unsur-unsur kimiawi dari sedimen: (c) isolat bakteri pengurai $N$ dan kemampuan penguraiannya. Laju sedimentasi diukur dengan menggunakan tabung sedimen yang dipasang di KJA pada kedalaman 1. 2, 4, 8, 14, 22, 32. $14 \mathrm{~m}$ dan di dasar perairan selama satu sampai empat hari. Kandungan unsur-unsur kimiawi dianalisis dari sampel sedimen yang diambil dari dasar perairan di bawah KJA. Isolasi bakteri pengurai $\mathrm{N}$ dari sampel sedimen dan uji kemampuan penguraiannya dilakukan di laboratorium. Hasil penelitian menunjukkan bahwa laju sedimentasi di lokasi budi daya KJA berkisar antara $5-10$ kali lipat laju sedimentasi di luar lokasi KJA, yaitu rata-rata $35,04-155.84 \mathrm{~cm}^{3} / \mathrm{m}^{\prime \prime} /$ hari. Nilai $\mathrm{pH}$, kandungan $\mathrm{N}, \mathrm{P}_{2} \mathrm{O}_{.,}$, dan $\mathrm{K}_{\mathrm{g}} \mathrm{O}$ sedimen di ketiga waduk tidak menunjukkan perbedaan y'ang berarti. sedangkan kandungan $\mathrm{CaO}, \mathrm{MgO}$. C-organik dan bahan organik total menunjukkan perbedaan yang nyata $(\mathrm{P}<0.05)$. Kandungan $\mathrm{CaO}, \mathrm{MgO}$, C-organik dan bahan organik total dj Waduk Saguling lebih tinggi jika dibandingkan dengan Waduk Cirata dan Jatiluhur. Sedimen dasar di bawah KJA memungkinkan untuk disedot dan dijadikan pupuk, karena kandungan unsur hara N. P dan Knya yang cukup tinggi. Bakteri pengubah amonia (Nitrosomonas) dengan kepadatan $100 \mathrm{sel} / \mathrm{ml}$. mamu mengubah sekitar 50\% kandungan amonia dalam arr.
\end{abstract}

\section{ABSTRACT: Analysis of waste sedimentation rate chemical composition of the sediment and nitrification rate of Nitrosomonas bacteria as a basic: information for water quality restoration in floating cage culture. By: Endi Setiadi Kartamihardja and Hambali Supriyadi.}

\begin{abstract}
Degradation of water quality caused by cage fish culture activity was detected in Saguling. Cirata and Jatiluhur reservoirs. A study was carried out to investigate some basic information for the restoration of water quality, i.e. (a) waste sedimentation ratr of the cage fish culture, (b) chemic al composition of the sediment under the cage culture and (c) nitrification rate of Nitrosomonas bacteria isolated from the sediment. The waste sedimentation rate was measured using a PVCsediment core plared in cage rulture site and control site at 1, 2, 4, 8, 14,22,32, $44 \mathrm{~m}$ depth and the bottom layer for one to four days. The sediment under the rage fish culture was sampled usins Eickman dredge and the samples were analysed in the laborctory. Nitrosomonas bacteria wa.s isolated from the sediment, cultured and its nitrification rate uas tested in the laboratoty. Results of the study showed that the waste sedimentation rate of the samples varried from $35.04 .155 .84 \mathrm{~cm}^{\prime \prime}$ $m^{3} /$ day which were higher five to ten times than that of the control site (out side cages). The p $H, N$, $P_{2} \mathrm{O}_{5}$ and $\mathrm{K}_{2} \mathrm{O}$ of the sediment in the three reservotrs were not significantly different. While the $\mathrm{CaO}$. $\overrightarrow{M g O}, C$-organic and total organic matter of the sediment from Saguling reservoir were higher than. those of Cirata and Jatiluhur reservoirs. Based on the $N, K$, and $P$ contents, the sediment can be used as an organic manure. The Nitrosomonas bacteria with a density of 100 cells $/ m L$ was ablo to change the $50 \%$ of amonia of the water media.
\end{abstract}

KEYWORDS: waste, sedimentation rate, nitrification rate, Nitrosomonas, cage cultur. reservoir:

"Peneliti pada Balai Penelitian Perikanan Air Tawar 


\section{PENDAHULUAN}

Degradasi kualitas perairan waduk yang digunakan untuk budi daya ikan secara intensif dalam keramba jaring apung (KJA) terjadi karena penerapan budi daya tersebut sudah melebihi daya dukung perairan (Kartamihardja, 1996). Kondisi tersebut terjadi di Waduk Saguling, Cirata dan Jatiluhur. Cemaran yang dihasilkan dari budi daya ikan di KJA terutama bersumber dari sisa pakan yang tidak termakan dan kotoran ikan. Praktek budi daya ikan dalam KJA yang dilakukan petani dengan cara pemberian pakan tambahan yang berlebihan (sistem pompa) menunjukkan bahwa sekitar $20-45 \%$ pakan yang diberikan terbuang ke perairan (Krismono, 1992; Krismono, 1995; Wahyudi et al., 1996).

Secara fisik, buangan sisa pakan dan kotoran ikan akan meningkatkan laju sedimentasi perairan. Dalam proses selanjutnya, sisa pakan dan kotoran ikan yang menumpuk di dasar perairan tersebut akan mengalami proses dekomposisi dan pembusukan, yang akan menghasilkan gas-gas beracun seperti amonia dan sulfida. Dalam proses dekomposisi tersebut diperlukan oksigen sehingga oksigen terlarut di perairan akan berkurang.

Amonia di perairan terdapat dalam dua bentuk yakni amonia yang terionisasi $(\mathrm{NH} 4+)$ dan yang tidak terionisasi $\left(\mathrm{NH}_{3}\right)$. Amonia yang tidak terionisasi lebih beracun dari pada $\mathrm{NH}_{+}^{+}$serta dapat mematikan ikan dan organisme perairan lainnya jika kadarnya lebih besar dari 0,1 mg/L (Boyd, 1982). Dalam proses nitrifikasi amonia dalam air akan dirombak oleh bakteri Nitrosomonas menjadi nitrit, kemudian nitrit oleh bakteri Nitrobacter diubah menjadi nitrat. Pada proses denitrifikasi, nitrat tersebut akan diubah menjadi gas nitrogen $(\mathrm{N})$ untuk kemudian dilepaskan ke udara.

Upaya-upaya perbaikan (restorasi) ekosistem dan menyeimbangkan perairan waduk melalui pendekatan eko-teknologi merupakan hal yang penting dilakukan untuk mengurangi degradasi mutu perairan tersebut. Untuk kelangsungan usaha budi daya ikan di KJA, salah satu upaya yang harus dilakukan adalah mengadakan restorasi perairan tersebut sehingga kualitas airnya layak bagi kehidupan ikan.

Metode yang dapat digunakan dalam restorasi adalah secara kimiawi, biologis dan fisik, serta kombinasi dari ketiganya. Dari metode tersebut perlu dicari cara-cara yang tepat, efektif dan efisien sesuai dengan permasalahan dan penyebab degradasi tersebut.

Untuk keperluan restorasi perairan tersebut diperlukan informasi dasar mengenai proses kimiawi ataupun biologis yang terjadi di perairan budi daya tersebut. Penelitian ditujukan untuk mendapatkan informasi dasar yang akan digunakan dalam restorasi perairan, yaitu: (a) laju sedimentasi bahan-bahan buangan yang berupa sisa pakan dan kotoran ikan dari kegiatan budi daya ikan di KJA, (b) kandungan unsur-unsur kimiawi terutama $\mathrm{P}, \mathrm{N}, \mathrm{K}, \mathrm{Ca}, \mathrm{Mg}$, bahan organik dari sedimen di bawah KJA, (c) isolat bakteri pengurai $\mathrm{N}$ dan uji kemampuan penguraiannya di laboratorium.

\section{BAHAN DAN METODE}

\section{Penentuan Laju Sedimentasi Bahan- bahan Buangan di KJA}

Laju sedimentasi bahan-bahan buangan dari KJA yang terutama berupa sisa pakan yang terbuang dan kotoran ikan diukur dengan menggunakan tabung sedimen (sedimen core) berdiameter $8,75 \mathrm{~cm}$ dan tinggi $25 \mathrm{~cm}$. Tabung sedimen tersebut digantungkan di KJA dan di luar lokasi KJA pada kedalaman 1, 2, 4, 8, 14, 22, 32, $44 \mathrm{~m}$ dan di dasar perairan. Tabung sedimen diangkat setelah dipasang selama satu, dua, tiga dan empat hari. Laju sedimentasi di lokasi KJA dan di luar KJA dibandingkan dengan menghitung banyaknya endapan per satuan luas tabung per waktu pemasangan.

\section{Analisis Kandungan Unsur-unsur Kimiawi Sedimen di Bawah KJA}

Sampel sedimen di bawah KJA diambil dengan menggunakan Eickman dredge, masing-masing dari tiga lokasi yaitu di Waduk Saguling, Cirata dan Jatiluhur. Analisis kimiawi sedimen terdiri atas $\mathrm{pH}$, kandungan $\mathrm{N}, \mathrm{P}_{2} \mathrm{O}_{5}, \mathrm{CaO}, \mathrm{MgO}, \mathrm{K}, \mathrm{O}, \mathrm{C}$ organik dan bahan organik total. Sampel sedimen dikeringkan, dihaluskan dengan cara ditumbuk untuk selanjutnya dianalisis dengan menggunakan spectrophotometer di Laboratorium Pusat Pene. litian Tanah dan Agroklimat Bogor.

\section{Isolasi dan Uji Kemampuan Bakteri Pengurai N}

Isolasi bakteri pengurai $\mathrm{N}$ dilakukan dengan metode Bullock (1977) dari sampel sedimen yang diambil dari dasar perairan maupun dari tabung sedimen di bawah KJA. Kultur bakteri pengurai N tersebut dilakukan dengan metode Watson et al. in Austin (1988). Uji kemampuan bakteri Nitrosomonas dilakukan di laboratorium. Akuarium dengan volume $50 \mathrm{~L}$ diisi air sebanyak $20 \mathrm{~L}$, kemudian ke dalam setiap akuarium dimasukkan amonia sehingga setiap akuarium mengandung amonia 
sekitar $0,3 \mathrm{mg} / \mathrm{L}$. Bakteri Nitrosomonas dengan kepadatan berbeda, yaitu $100 \mathrm{sel} / \mathrm{mL}, 1000 \mathrm{sel} / \mathrm{mL}$ dan $10.000 \mathrm{sel} / \mathrm{mL}$ diinokulasikan kedalam akuarium. Akuarium yang tidak diinokulasi bakteri Nitrosomonas digunakan sebagai kontrol. Setiap perlakuan diulang sebayak lima kali. Pengukuran kandungan amonia dilakukan pada awal (sebelum inokulasi bakteri) dan akhir percobaan (setelah 10 hari). Rancangan percobaan yang digunakan adalah rancangan acak lengkap. Untuk mengetahui pengaruh tiap perlakuan digunakan uji $\mathrm{F}$, dan untuk mengetahui perbedaan antar perlakuan digunakan uji jarak berganda Duncan (Walpole \& Myers, 1990).

\section{HASIL DAN BAHASAN}

\section{Laju Sedimentasi Bahan-bahan Buangan di KJA}

Laju sedimentasi bahan-bahan buangan dari KJA rata-rata berkisar antara $35,04-155,84 \mathrm{~cm}^{3} / \mathrm{m}^{2} / \mathrm{h}$ ari, sedangkan laju sedimentasi di luar lokasi KJA rata- rata berkisar antara $3,28-47,19 \mathrm{~cm}^{3} / \mathrm{m}^{2} /$ hari. Profil sedimentasi menurut kedalaman perairan tertera pada Gamıbar 1. Profil sedimentasi di lokasi K.JA sekitar 5 sampai 10 kali dari sedimentasi di luar KJA. Hal ini menandakan bahwa dengan adanya kegiatan budi daya maka sedimentasi waduk akan bertambah sekitar 5 sampai 10 kali dibandingkan jika tidak ada kegiatan budi daya KJA.

Merican \& Philips (1985) melaporkan bahwa laju sedimentasi pada budi daya intensif ikan trout di keramba berkisar antara 14-203 g bahan kering/ $\mathrm{m}^{2} /$ hari dengan rata-rata $16,43 \mathrm{~g}$ bahan kering/ $\mathrm{m}^{2} /$ hari. Selanjutnya dikatakan bahwa jumlah buangan sedimen dari KJA tersebut tergantung kepada ukuran ikan dan berkorelasi positif dengan laju pemberian pakan. Jika diasumsikan bahwa kandungan air dalam sedimen tersebut adalah sekitar $80 \%$, maka laju sedimentasi pada budi clava ikan mas di KJA dalam penelitian ini jauh lebih kecil dari laju sedimentasi pada budi daya ikan trout tersebut. Hal ini sesuai dengan pernyatian

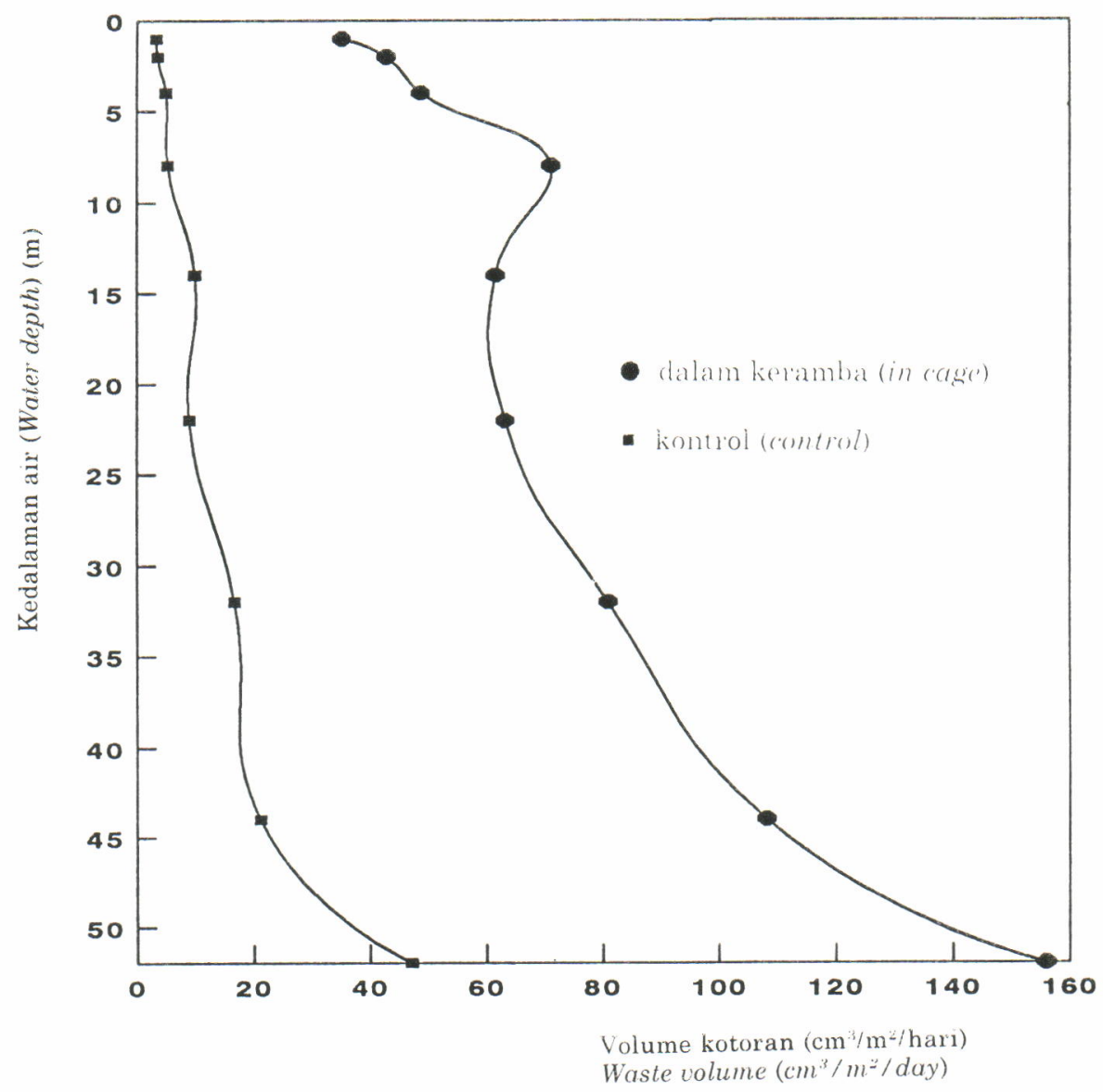

Gambar 1. Laju sedimentasi sisa pakan dan kotoran ikan pada budi daya KJA.

Figure 1. Sedimentation rate of the uneaten feed and waste product from floating cage culture. 
Merican \& Philips (1985) bahwa laju sedimentasi akan bervariasi cukup besar dan diperkirakan berhubungan dengan perbedaan ukuran pellet, padat penebaran dan kesehatan ikan.

Sedimen yang berupa buangan sisa pakan dan kotoran ikan tersebut akan menumpuk di dasar perairan untuk selanjutnya mengalami dekomposisi atau penguraian. Penambahan buangan bahan organik ke dasar perairan dalam jumlah yang relatif kecil akan merangsang aktivitas bakteri, jamur dan makro-invertebrata sehingga meningkatkan konsumsi oksigen di sedimen. Beveridge (1987) menyatakan bahwa laju konsumsi oksigen sedimen pada budi daya keramba ternyata dua kali lebih tinggi dari pada laju konsumsi oksigen di perairan yang tidak ada keramba. Dalam keadaan laju sedimentasi bahan buangan tinggi, laju pasokan oksigen mungkin tidak akan mencukupi kebutuhan untuk respirasi komunitas makrobentik dan mikroba. Dengan demikian, sedimen akan bersifat anoxic, komunitas bentos berubah menjadi jenis yang toleran terhadap kandungan oksigen rendah dan anaerob, dan sebagai hasil akhir dari aktivitas kimiawi dan biologis ini adalah direduksinya senyawa-senyawa organik dan anorganik seperti laktat, amonia, methan dan hidrogen sulfida. Meskipun dasar perairan mempunyai kemampuan untuk mengikat senyawa-senyawa tersebut (self purification), dalam keadaan terdapat buangan sisa pakan dan kotoran ikan yang berlebihan akan berpengaruh negatif terhadap kualitas air.
Laju konsumsi oksigen yang tinggi oleh sedimen akan menyebabkan deoksigenasi (pengurangan kelarutan oksigen) dari lapisan perairan, yang akan mempengarulii kesehatan ikan dan jika terjadi pembalikan atau pengadukan lapisan air (up welling) dapat menyebabkan kematian massal ikan budi daya. Buangan sedimen KJA tersebut juga merupakan timbunan unsur hara potensial yang dalam kondisi tertentu akan melepaskan unsur nitrogen dan fosfor ke lapisan air sehingga memacu pertumbuhan alga. Oleh karena itu, akumulasi buangan di bawah dan sekitar budi daya KJA harus merupakan suatu fokus perhatian khusus oleh setiap pembudi daya.

\section{Kandungan Unsur-unsur Kimiawi Sedimen di Bawah KJA}

Kandungan unsur-unsur kimiawi sedimen di bawah KJA tertera pada Tabel 1. Nilai pH, kandungan $\mathrm{N}, \mathrm{P}_{2} \mathrm{O}_{5}$, dan $\mathrm{K}_{2} \mathrm{O}$ sedimen di ketiga waduk tidak menunjukkan perbedaan yang nyata. Sedangkan kandungan $\mathrm{CaO}, \mathrm{MgO}, \mathrm{C}$-organik dan bahan organik total menunjukkan perbedaan yang nyata. Dengan demikian, lamanya penerapan budi daya ikan di KJA (di mana budi daya ikan KJA di Saguling yang terlama, kemudidan disusul oleh Cirata dan Jatiluhur), hanya menghasilkan peningkatan kandungan $\mathrm{CaO}, \mathrm{MgO}$ dan bahan organik. Secara umum. kandungan unsur hara N, P dan K di sedimen cukup tinggi sehingga melalui penyedotan sedimen tersebut dimungkinkan untuk dapat digunakan sebagai pupuk. Penyedotan sedimen di bawah KJA

Tabel 1. Kandungan unsur-unsur kimiawi sedimen di bawah KJA di Waduk Jatiluhur, Cirata dan Saguling.

Table 1. Chemical composition of the sediments under floating cage culture at Jatiluhur, Cirata and Saguling reservoirs.

\begin{tabular}{lcccccc}
\hline \multirow{2}{*}{$\begin{array}{c}\text { Peubah } \\
\text { Parameter }\end{array}$} & \multicolumn{2}{c}{$\begin{array}{c}\text { Waduk Jatiluhur } \\
\text { Jatiluhur reservoir }\end{array}$} & \multicolumn{2}{c}{$\begin{array}{c}\text { Waduk Cirata } \\
\text { Cirata reservor }\end{array}$} & \multicolumn{2}{c}{$\begin{array}{c}\text { Waduk Saguling } \\
\text { Saguling reservoir }\end{array}$} \\
\cline { 2 - 8 } & $\begin{array}{c}\text { Kisaran } \\
\text { Range }\end{array}$ & $\begin{array}{c}\text { Rata-rata } \\
\text { Average }\end{array}$ & $\begin{array}{c}\text { Kisaran } \\
\text { Range }\end{array}$ & $\begin{array}{c}\text { Rata-rata } \\
\text { Average }\end{array}$ & $\begin{array}{c}\text { Kisaran } \\
\text { Range }\end{array}$ & $\begin{array}{c}\text { Rata-rata } \\
\text { Average }\end{array}$ \\
\hline $\mathrm{pH}$ & $6.3-6.5$ & 6.43 & $6.2-6.3$ & 6.23 & $6.1-6.2$ & 6.13 \\
$\mathrm{~N}(\%)$ & $0.52-0.92$ & 0.72 & $0.40-0.94$ & 0.632 & $0.42-0.59$ & 0.482 \\
$\mathrm{P}_{2} \mathrm{O}(\%)$ & $0.018-0.024$ & 0.021 & $0.019-0.021$ & 0.02 & $0.019-0.021$ & 0.02 \\
$\mathrm{CaO}(\%)$ & $0.095-0.130$ & 0.113 & $0.103-0.361$ & 0.205 & $0.089-0.694$ & 0.306 \\
$\mathrm{MgO}(\%)$ & $0.224-0.341$ & 0.283 & $0.103-0.361$ & 0.205 & $0.297-0.364$ & 0.338 \\
$\mathrm{~K}_{2} \mathrm{O}(\%)$ & $0.040-0.041$ & 0.041 & $0.035-0.058$ & 0.044 & $0.026-0.038$ & 0.032 \\
$\mathrm{C}-\mathrm{organic}(\%)$ & $1.900-1.997$ & 1.949 & $1.652-2.574$ & 1.987 & $2.060-2.422$ & 2.197 \\
$\mathrm{TOM}(\%)$ & $3.268-3.435$ & 3.352 & $2.840-4.430$ & 3.418 & $3.543-4.166$ & 3.779 \\
\hline
\end{tabular}


ini diperkirakan akan memberikan dampak positif terhadap peningkatan kualitas perairan di lokasi tersebut. Dengan demikian, jika terjadi umbalan (pembalikan air) di lokasi tersebut tidak akan mematikan ikan budi daya, karena air dari lapisan dasar yang naik ke lapisan atas mempunyai kualitas yang baik.

\section{Isolasi dan Uji Kemampuan Bakteri Nitrosomonas}

Dari sampel sedimen dasar perairan maupun dari tabung sedimen di bawah KJA telah berhasil diisolasi bakteri pengubah $\mathrm{N}$, yaitu Nitrosomonas. Hasil uji kemampuan bakteri pengurai amonia (Nitrosomonas) pada kepadatan berbeda tertera pada Tabel 2.

Bakteri Nitrosomonas dengan kepadatan 100 sel/mL sudah mampu mengubah amonia sekitar setengahnya dari kandungan amonia awal. Perlakuan tanpa bakteri sangat berbeda nyata dengan perlakuan bakteri dan antar perlakuan bakteri tidak menunjukkan perbedaan yang nyata $(\mathrm{P}<0,05)$.

Tabel 2. Kadar amonia $(\mathrm{mg} / \mathrm{L})$ air dalam akuarium pada akhir percobaan menurut perlakuan kepadatan bakteri Nitrosomonas.

Table 2. Amonia ( $\mathrm{mg} / \mathrm{L}$ ) of water media at final of experiment by treatment of Nitrosomonas bacteria.

\begin{tabular}{ccccc}
\hline \multirow{2}{*}{$\begin{array}{c}\text { Ulangan } \\
\text { Replication }\end{array}$} & $\begin{array}{c}\text { Kontrol } \\
\text { Control }\end{array}$ & $\begin{array}{c}100 \mathrm{sel} / \mathrm{mL} \\
100 \mathrm{cells} / \mathrm{mL}\end{array}$ & $\begin{array}{c}\text { Kontrol } \\
\text { Control }\end{array}$ & $\begin{array}{c}100 \mathrm{sel} / \mathrm{mL} \\
100 \mathrm{cells} / \mathrm{mL}\end{array}$ \\
\cline { 2 - 5 } & 0.254 & 0.109 & 0.149 & 0.153 \\
2 & 0.226 & 0.146 & 0.178 & 0.182 \\
3 & 0.191 & 0.178 & 0.113 & 0.165 \\
5 & 0.250 & 0.170 & 0.133 & 0.137 \\
5 & 0.258 & 0.131 & 0.102 & 0.107 \\
Ruta-rata & & & & $0.1486^{\mathrm{b}}$ \\
\hline
\end{tabular}

Nilai rata-rata yang diikuti dengan notasi huruf yang sama tidak berbeda nyata $(P>0), 05)$ Average values in columns followed by the same superscript are not significantly different (P>0).(1).j).

Tabel 3. Kadar nitrit (mg/L) air dalam akuarium pada awal clan akhir percobaan menurut perlakuan kepadatan bakteri Nitrosomonas.

Table 3. Nitrite $(\mathrm{mg} / \mathrm{L})$ of the water media at initial and final of experiment by treatment of Nitrosomonas bacteria.

\begin{tabular}{|c|c|c|c|c|c|c|c|c|}
\hline \multirow{2}{*}{$\begin{array}{c}\text { Ulangan } \\
\text { Replication }\end{array}$} & \multicolumn{2}{|c|}{$\begin{array}{l}\text { Kontrol } \\
\text { Control }\end{array}$} & \multicolumn{2}{|c|}{$\begin{array}{l}100 \text { cells } / \mathrm{mL} \\
100 \text { cells } / \mathrm{mL}\end{array}$} & \multicolumn{2}{|c|}{$\begin{array}{l}1.000 \text { cells } / \mathrm{mL} \\
1,000 \text { cells } / \mathrm{mL}\end{array}$} & \multicolumn{2}{|c|}{$\begin{array}{l}10.000 \text { cells } / \mathrm{mL} \\
10,000 \text { cells } / \mathrm{mL}\end{array}$} \\
\hline & $\begin{array}{l}\text { Awal } \\
\text { Initial }\end{array}$ & $\begin{array}{c}\text { Akhir } \\
\text { Final }\end{array}$ & $\begin{array}{l}\text { Awal } \\
\text { Initial }\end{array}$ & $\begin{array}{l}\text { Akhir } \\
\text { Final }\end{array}$ & $\begin{array}{l}\text { Awal } \\
\text { Initial }\end{array}$ & $\begin{array}{l}\text { Akhir } \\
\text { Final }\end{array}$ & $\begin{array}{l}\text { Awal } \\
\text { Initial }\end{array}$ & $\begin{array}{l}\text { Akhir } \\
\text { Final }\end{array}$ \\
\hline 1 & 0.022 & 0.050 & 0.019 & 0.260 & (). 022 & 0.147 & 0.027 & 0.196 \\
\hline 2 & 0.030 & 0.074 & 0.023 & 0.181 & 0.030 & 0.255 & 0.026 & 0.111 \\
\hline 3 & 0.033 & 0.130 & 0.031 & 0.140 & (0.034 & 0.282 & 0.018 & 0.10 .3 \\
\hline 4 & 0.029 & 0.091 & 0.038 & 0.150 & ().032 & 0.260 & 0.027 & 0.208 \\
\hline 5 & 0.027 & 0.086 & 0.021 & 0.250 & 0.018 & 0.172 & 0.032 & 0.239 \\
\hline $\begin{array}{l}\text { Rata-rata } \\
\text { Average }\end{array}$ & 0.028 & $0.0860^{\mathrm{a}}$ & 0.0264 & $0.1960^{\prime \prime}$ & 0.0272 & $0.2232^{b}$ & 0.026 & $0.1711^{1}$ \\
\hline
\end{tabular}

Nilai rata-rata yang diikuti dengan notasi huruf yang sama tidak berbeda nyata $(P>0,(05)$

Average values in columns followed by the same superscript are not significantly different (P>0.05). 
Kemampuan bakteri Nitrosomonas dalam menguraikan amonia juga ditunjukkan dengan meningkatnya kandungan nitrit sebagai hasil antara dari proses pengubah amonia oleh bakteri tersebut (Tabel 3).

Kandungan nitrit pada perlakuan bakteri Nitrosomonas sangat berbeda nyata dengan perlakuan tanpa bakteri, namun kandungan nitrit antar perlakuan bakteri tidak berbeda nyata $(\mathrm{P}<0,05)$. Penurunan kandungan amonia dan peningkatan kandungan nitrit tertera pada Gambar 2. Kandungan nitrit yang terbentuk dapat diubah kembali menjadi nitrat dengan bantuan bakteri Nitrobacter. Nitrat yang terbentuk sudah merupakan senyawa yang tidak beracun terhadap ikan, malahan digunakan oleh organisme tumbuhan untuk pembentukan enersi. Nitrat yang terbentuk melalui proses denitrifikasi dapat diuraikan lagi menjadi nitrogen yang kemudian dilepaskan ke udara.

\section{KESIMPULAN DAN SARAN}

(1) Laju sedimentasi buangan budi daya KJA berkisar antara 35,04-155,84 $\mathrm{cm}^{3} / \mathrm{m}^{2} /$ hari, sedangkan laju sedimentasi di luar lokasi KJA rata-rata berkisar antara $3,28-47,19 \mathrm{~cm}^{3} / \mathrm{m}^{2} /$ hari.
(2) Nilai $\mathrm{pH}$, kandungan $\mathrm{N}, \mathrm{P}_{2} \mathrm{O}_{5}$, dan $\mathrm{K}_{2} \mathrm{O}$ sedimen di ketiga waduk tidak menunjukkan perbedaan yang nyata, sedangkan kandungan $\mathrm{CaO}, \mathrm{MgO}$, C-organik clan bahan organik total menunjukkan perbedaan yang nyata. Kandungan $\mathrm{CaO}, \mathrm{MgO}$, C-organik dan bahan organik total di Waduk Saguling lebih tinggi jika dibandingkan dengan Waduk Cirata dan Jatiluhur. Secara umum, kandungan unsur hara N, P dan $\mathrm{K}$ dari sedimen cukup tinggi sehingga memungkinkan untuk digunakan sebagai pupuk tanaman. Upaya penyedotan sedimen tersebut dapat meningkatkan kualitas perairan di lokasi budi daya tersebut.

(3) Isolasi bakteri pengurai amonia dari sedimen telah berhasil mendapatkan isolat bakteri Nitrosomonas. Bakteri Nitrosomonas dengan kepadatan $100 \mathrm{sel} / \mathrm{mL}$ telah mampu mengubah sekitar $50 \%$ kandungan amonia dalam air.

(4) Penelitian selanjutnya yang perlu dilakukan adalah uji kemampuan bakteri pengurai nitrit, yaitu Nitrobacter sehingga nitrit yang dihasilkan dari pengubah amonia dapat diubah dalam bentuk nitrat yang tidak toksik terhadap ikan dan organisme perairan lainnya.

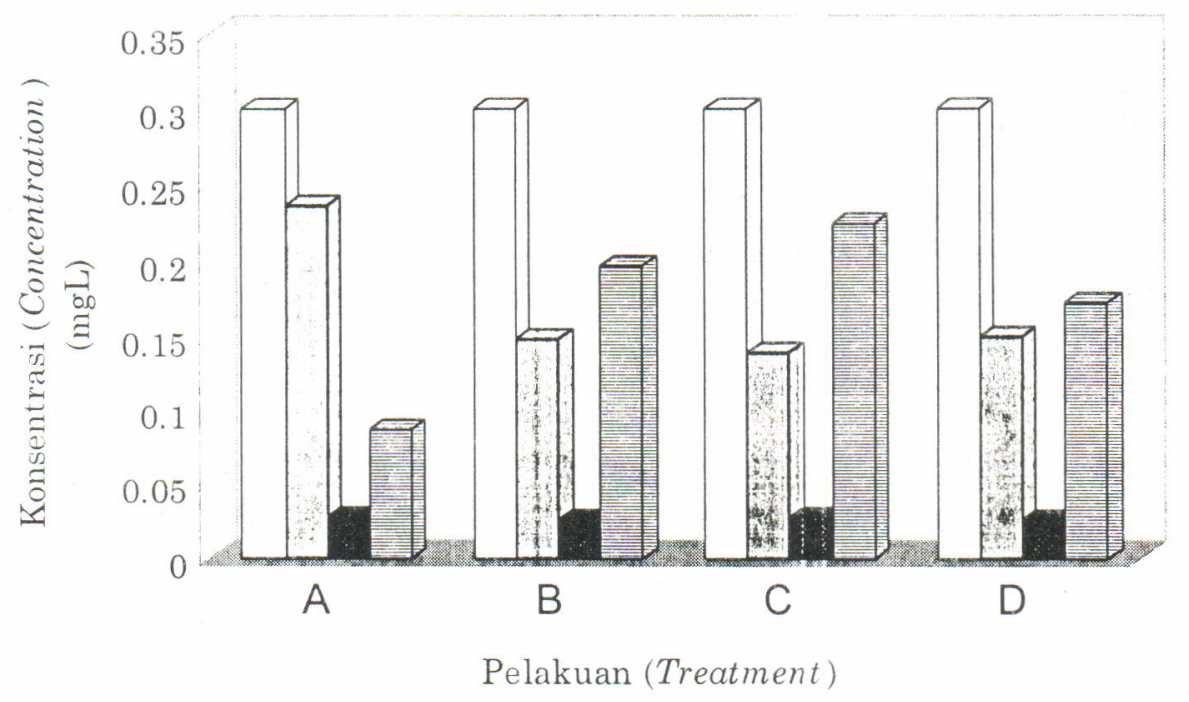

\begin{tabular}{|lcc|}
\hline $\begin{array}{l}\text { Nitrit awal } \\
\text { Nitrite at initial }\end{array}$ & Nitrit akhir & Amonia awal \\
Nitrite at final & Ammonia at initial & Amonia akhir \\
Ammonia at final
\end{tabular}

Gambar 2. Kandungan amonia dan nitrit pada perlakuan bakteri Nitrosomonas. Figure 2. Amonia and nitrite at the treatments of Nitrosomonas bacteria. 


\section{DAFTAR PUSTAKA}

Austin. B. 1988. Method in Aquatic Bacteriology. John Wiley \& Sons. A Wiley Interscience Publication. 425 $\mathrm{pp}$.

Beveridge. M.C.M. 1987. Cage Aquaculture. Fishing News Books Ltd. Farnham. Surrey. England. 351 pp.

Boyd, C.E. 1982. Water Quality Management for Pond Fish Culture. Elsevier Sci. Pub. Comp. New York. $318 \mathrm{pp}$.

Bullock. G.L. 1977. Identification of fish pathogenic bacteria. Book 2B. S.F. Sniezko and, H.R. Axelrod (ed.) In: Sniezko. S.F. and H.R. Axelrod (ed.). Disease of Fishes. TFH Publication.

Kartamihardja, E.S. 1996. Daya dukung perairan dan pengembangan budidaya ikan dalam keramba jaring apung yang ramah lingkungan. Prosiding Ekpose Budidaya Ikan dalam Keramba Jaring Apung yang Ramah Lingkungan. Pusat Penelitian dan Pengembangan Perikanan. 13-22.

Krismono. 1992. Hubungan antara tingkat trofik dengan produksi keramba jaring apung mini di suatu badan air. Bull. Penel. Perikanan. (1); 45-50.
Krismono. 1995. Tata ruang perairan umum mendukung agribisnis dan agroindustri. Dalam Cholik et al.(eds). Simposium Perikanan Indonesia I Buku II, Bidang Sumber Day'a Perikanan dan Penangkapan. Jakarta 25-27 Agustus 1993. 291 298.

Merican. Z.O. and Philips. M.J. 1985. Solid waste production from rainbow trout. Salmo gairdineri. Richardson in cage culture. Aquacult. Fish. Management. 16. 55-70.

Walpole, R.E. and Myers. R.H. 1990. Probability and Sstatistics for Engineers and Srientists. 1 ed. MacMillan Pub. Company. New York. $765 \mathrm{pp}$.

Wahyudi, N., Wardoyo, S.E.. Pranowo, S.A. Suhenda. N.. Krismono dan Priono. B. 1996. Penelitian sisa pakan ikan mas yang tidak termakan dalam pemeliharaan di Keramba Jaring Apung dengan kepadatan dan jumlah pakan harian yang berbeda. Laporan Hasil Penelitian Balithanwar tahum 1995/ 1996. (tidak dipublikasikan). 